\title{
THE IMPLEMENTATION OF CHILDRENADOPTION LICENSING IN THE BENGKULU PROVINCE BASED ON GOVERNMENT REGULATION NUMBER 54 OF 2007 CONCERNING THE IMPLEMENTATION OF CHILDREN ADOPTION
}

\author{
By: \\ Willy Purnama Hidayanti, Edra Satmaidi, Amancik
}

\begin{abstract}
The State and the Government are obliged and responsible for the orderliness of children adoption practices, both in terms of administration and legal certainty. Therefore several policies were issued through legislation and jurisprudence that regulates and handles the issue of children adoption. The implementation of children adoption must be based on Government Regulation of the Republic of Indonesia Number 54 of 2007 concerning Children Adoption. This study aims to get an overview and explanation of the Implementation of Licensing for ChildrenAdoption in Bengkulu Province Based on Government Regulation 54 of 2007 concerning the Implementation of Children Adoption. The children adoption process requires regulations that are in accordance with the Laws and Government Regulations and needs control of how they are implemented in the field. In addition to the Social Department of Bengkulu Province as the technical executor of adoption activities, it is necessary to establish a Regional Consultation Team for Children Adoption (known as PIPA in Indonesian abbreviation), to avoid irregularities in the process of implementation of children adoption, such as the adoption of children carried out without proper procedures, falsification of data and the existence of child trafficking, so the goal of adopting a child for the best interests of the child is not achieved. In analyzing the data in this thesis, the researcher applied a qualitative juridical analysis approach that describes the picture of the data obtained by researcher in the field and connects with each other to get a general conclusion. From the results of the qualitative juridical analysis, it can be seen and obtained inductive conclusions, namely the way of thinking in taking conclusions in general was based on facts that are specific. Data collection methods in this study were done through in-depth interview techniques, observation and documentation. The informants in this study were determined by selecting informants who comprehended and were directly involved in the implementation of child adoption programs. The informants consisted of the Head of Social Rehabilitation Division at the Social Department of Bengkulu Province, Head of Children and Elderly Social Rehabilitation Section at the Social Department of Bengkulu Province, Head of ChildrenProtection Section of the Women Empowerment Department and Children Protection in Bengkulu Province, Children Social Workers and Parents or Prospective Adoptive Parents who follow procedural for children adoption in accordance with applicable regulations. Data processing and analysis were conducted through data reduction, data presentation and conclusion drawing.
\end{abstract}

Keywords: Children, Children Adoption, Children Protection, Implementation of PP 54 of 2007, Best Interests for Children, PIPA Team 


\section{A. INTRODUCTION}

\section{Research Background}

Children are gift and mandate given by God Almighty, therefore children must always be guarded and protected by families, communities, countries because in children inherent children's rights which are part of human rights contained in the 1945 Constitution, children are heirs as well as successors to the family line. Therefore, if a marriage has not or has not been blessed with a child, then one of the efforts is the adoption. The definition of adoption can be seen etymologically, terminologically, and according to legal experts.

Based on the Government Regulation of the Republic of Indonesia Number: 54 of 2007 concerning the Implementation of Children Adoption in Chapter I Article 1 (2) Children Adoption is:

A legal act that diverts a child from the sphere of authority of a parent, legal guardian or other person who is responsible for the care, education and raising of the child into the foster parent's family environment. ${ }^{1}$

The state and the government are obliged and responsible for the

\footnotetext{
${ }^{11}$ Government Regulation of the Republic of Indonesia Number 54 of 2007 on the Implementation of Children Adoption
}

orderliness of the practice of children adoption, both in terms of administration and legal certainty, the implementation of children adoption must be based on Government Regulation of the Republic of Indonesia Number 54 of 2007 concerning Children Adoption.

Based on the Regulation of the Minister of Social Affairs of the Republic of Indonesia Number 110/HUK/2009 concerning Requirements for Children Adoption, in Chapter IV Article 12 it is stated that the Minister has the authority to grant the License for Children Adoption to be subsequently determined to the Court, and based on Chapter I Article 1 (5) of Law No. 23 of 2014 concerning Regional Government, stated:

Regional government affairs are government authorities which become the authority of the President of which the implementation is carried out by the State Ministry and Regional Government Organizers to protect, serve, empower, and prosper the community. ${ }^{2}$

This means that the Minister of Social Affairs can delegate the implementation of the granting of a

2 Law of the Republic of Indonesia Number 23 of 2014 on Regional Government 
Children Adoption permit to the Governor through the Head of the Provincial Social Department.

Furthermore, the Head of the Regency/City Social Department has the authority to provide recommendations on the application for Children Adoptionpermit within the local Regency/City to be submitted to the Regional Consultation Team for Children Adoption (known as PIPA in Indonesian abbreviation) consisting of several elements from the relevant Department/Agency in the Province.

Problems in children adoption are so complex and full of legal rules that must be obeyed. Besides that, there are other motivations in adopting a child that are feared to make the goal of adopting the child itself is not achieved. To ensure that the purpose of adoption is for the good and the future of adopted children and to provide protection and certainty for the rights of adopted children, this is the basis for the need to form a team that monitors the adoption procedure called the PIPA Team.

In Bengkulu Province the PIPA Team was just formed in 2015 with the issuance of a Decree of PIPA Team in Bengkulu Province, the PIPA Team was a team formed as a Consultation Team for Children Adoption. In its implementation, the PIPA Team of Bengkulu Province encountered many obstacles including: children adoption is still often done by illegally the public, which is only marked by a birth confirmation letter from the midwife; many parties, especially the public do not know the procedures to go through; budget support from the Regional Government to the maximum PIPA Team's work is still limited; and there is no clear understanding and coordination between the Regency Social Department and the Provincial Social Department regarding their respective duties and responsibilities.

In Bengkulu Province, through the Social Department of Bengkulu Province in 2017 there were 12 children and in 2018 there were 8 children whose appointment process was done through the PIPA Team process, namely through the assessment process, filing, fostering permit, PIPA Team session and decision making in court so that appear later whether the child can be adopted or not. Of the many cases of children adoption in Bengkulu Province, only 12 children were 
adopted legally. The researchers considered that there are things that must be evaluated from the performance of the Regional Government. From 2008, ideally the Bengkulu Provincial Government should have been provided socialization, reinforcement and support to various parties to introduce the legal adoption process, but unfortunately this has not been done to the maximum, so that until now the case of children adoption obscuring family pedigree has become commonplace. Another case that occurred was asking for fake documents Birth Certificate from medical personnel stating that having gone through the process of childbirth is a common thing to be done even though according to a Government Regulation year 2007 and technically clarified through the Minister of Social Regulations Republic of Indonesia Number: 110/HUK/2009 concerning Requirements for Appointment of Children it is a violation of law that must not be carried out.

Based on the description above, the author was interested in further researching the implementation of Children Appointment through the Provincial
Social Department in the perspective of Children Protection, and how the relevant Regional Apparatus Organizations involved in the PIPA Team of Bengkulu Province carried out their functions in an effort to provide Protection of Children especially against Prospective Foster Children (known as CAA in Indonesian abbreviation), so the authors chose the

title

of:"THE

IMPLEMENTATION OF CHILDREN ADOPTION LICENSING IN THE BENGKULU PROVINCE BASED ON GOVERNMENT REGULATION $\begin{array}{llll}\text { NUMBER } & 54 & \text { OF } & 2007\end{array}$ CONCERNING THE IMPLEMENTATION OF CHILDREN ADOPTION".

\section{Identification of Problems}

1. Has the implementation of licensing for children adoption in Bengkulu Province based on Government Regulation Number 54 of 2007 ?

2. What were the obstacles faced in the process of implementing the Licensing for children adoption in Bengkulu Province?

\section{B. RESEARCH METHODS}




\section{Type of Research}

The type of this research was Empirical Juridical Research. Empirical Juridical Research is another term used in sociological legal research, which starts from primary data. ${ }^{3}$ Empirical legal research is one type of legal research that analyzes and examines the operation of law in society. ${ }^{4}$ Empirical research is also called socio-legal research where the most often topic in research is the problem of the effectiveness of the rule of law, compliance with the rule of law, the role of legal institutions or institutions in law enforcement, implementation of the rule of law, the effect of the rule of law on certain legal issues or vice versa. ${ }^{5}$

\section{Research Approach}

The type of research approach in this study was descriptive qualitative juridical.

\section{Research Location}

This research was conducted at Bengkulu Province Social
Department, and Bengkulu Province Women Empowerment and Children Protection Agency.

\section{Population and Samples}

The sampling technique in this study usedthe Purposive Sampling. The population and sample to be used in this study were Prospective Foster Parents (known as COTA in Indonesian abbreviation) in the Bengkulu Province region as recipients of Foster Permits from the Bengkulu Province Social Department. Prospective Foster Parents (COTA) who were referred by the Bengkulu Province Social Departmentthat became informants for researcher, namely:

1. Head of Social Rehabilitation Division of Bengkulu Province Social Department as Chairperson of PIPA Team;

2. Head of Section for the Social Rehabilitation of Children and Elderly of the Bengkulu Province Social Department as the Secretary of the PIPA Team;

3. Social Workers (Sakti PEKSOS), namely professional

\footnotetext{
${ }^{3}$ Suratman and Philips Dillah, MetodePenelitianHukumDilengkapiDengan Tatg Cara danContohPenul

${ }^{4}$ Salim HS and Erlies Septiana Nurbani, Buku Kedua Penerapan Teori Hukum Pada Penelitian Disertasi dan Tesis, PT. Raja Grafindo Persada, Jakarta, p.20.

5 Suratman and Philips Dillah, Op.Cit,

Bengkulu City and Kaur

Regency;
} p.88.
4. Head of the Children 
Protection Section in the $P P H$ -

$P A$ Division of the Bengkulu

Province

Women

Empowerment and Children

Protection Agency.

\section{Data Analysis}

The approach used by the author in analyzing the data in this thesis was qualitative juridical analysis approach that describes the picture of the data obtained by researchers in the field and connects with each other to get a general conclusion. From the results of the qualitative juridical analysis, it can be seen and obtained inductive conclusions, namely the way of thinking in taking conclusions in general based on facts that were specific. ${ }^{6}$ Furthermore, the results research both from interviews and analysis were described to answer the issues raised, and arranged into scientific work in the form of a thesis.

\section{RESULTS AND DISCUSSION}

1. Description of Research Area (Social Welfare Department of Bengkulu Province)

6 SoerjonoSoekanto, PengantarPenelitianHukum, Universitas Indonesia Press, Jakarta. 1986, p.112.
From the description of the tasks and functions of the Bengkulu Province Social Department, the important point of the main tasks and functions is the preparation of the implementation of social rehabilitation policies for children, especially those concerning public services in the process of adopting children. Preparation of material for the implementation of the children adoption policy process, including:

1. Preparation of Governor's Decree regarding the establishment of a Consultation Team for Children Adoption (PIPA Team);

2. Implementation of counseling about the children adoption procedures;

3. Provide counseling to prospective adoptive parents (COTA) both COTA who will submit the requirements and procedures for children adoption. Assistance to Prospective Adoptive Parents (COTA) in order to help smoothen the process of filing for children adoption.

\section{Implementation of Appointment}

of Children by Prospective Adoptive Parents and Efforts by the Provincial Social 


\section{Department}

Regulations on the children adoption have been regulated in the Law of the Republic of Indonesia Number 35 of 2014 concerning Amendment to Law Number 23 of 2002 concerning Children Protection which is supported by Government Regulation Number 54 of 2007 which is more technically explained and detailed in Ministerial Regulation Social Number 110/HUK/2009 concerning Requirements for Children Adoption. The regulation states that the adoption of a child can only be done in the best interests of the child, and may not sever blood relations between the adopted child and his biological parents.

\section{Authority of Bengkulu Province}

Consultation Team for Children

\section{Adoption}

A. Duties and Functions of the Consultation Team for Children Adoption in the Process of Children Adoption Based on the provisions of Article 8 paragraph (1) of the Minister of Social Affairs Number 110/HUK/2009 concerning Requirements for the Central Children Adoption, it was formed a Regional Consultation Team for Children Adoption of Bengkulu Province based on the Decision of Governor of Bengkulu.

The task of the Regional Consultation Team for Children Adoption of Bengkulu Province is to help the Governor in this case the Head of Social Departments to give consideration in granting permission for childrenadoption carried out among Indonesian Citizens or providing Recommendations for children adoption, one of whom is a Prospective Foster Parent of a Foreign Citizen.

In carrying out this task the Regional Consultation Team for Children Adoption of Bengkulu Province functions to: ${ }^{7}$

a. Carry out research and study as well as provide consideration of the application for permission for children adoption;

b. Provide advice in accordance with the provisions, the main tasks and functions of each member based on established

\footnotetext{
${ }^{7}$ Decision of Governor of Bengkulu Number IV.156.DINSOS of 2017 on Regional Consultation Team for Children Adoption of Bengkulu Province of 2017.
} 
requirements;

c. Deliver reports on the results of the execution of tasks for the Regional Consultation Team for Children Adoption of Bengkulu Province to the Governor of Bengkulu;

d. Conduct training and supervision of the implementation of licensing children adoption in accordance with their fields of work;

According to Article 24 of the Minister of Social Affairs Regulation Number 110/HUK/2009 concerning Requirements for Children Adoption, the Prospective Foster Parent Requirements for children adoption through the Childcare Institution include:

a. Material requirements; and

b. Administrative requirements.

Prospective Foster Parent administrative requirements as referred to in Article 24 letter b, i.e. there must be 24 items attached, one of them is to attach a Recommendation Letter for Consideration of Children Adoption from the Regional PIPA Team. The function of the Consultation Team for Children Adoptionas mentioned above, in the practice of children adoption that occurred so far in Bengkulu Province, was carried out by the Provincial Regional PIPA Team chaired by the Head of Social Rehabilitation Division, Head of the Section for Child and Elderly Social Rehabilitation as Team Secretary, and several members consist of the Regional Agency Departments in the Province and the Vertical Agency in charge.

B. The Synergy of the Regional Consultation Team for Children Adoption of Bengkulu Province Regional Consultation Team for Children Adoption of Bengkulu Province was formed based on Bengkulu Governor Decree Number IV.156.DINSOS of 2017 dated on $18^{\text {th }}$ April 2017 in the Regulation of the Minister of Social Affairs Number 37/HUK/2010 concerning the Central Consultation Team for Children Adoption of with Position, Duties, Functions and PIPA Team Work Procedures are based on the principles of Empowerment, Partnership, Accountability, Credibility, Transparency, Effectiveness, and Efficiency.

The PIPA Team is a 
comprehensive and integrated forum for cross-agency coordination meetings to provide consideration for granting permission for adoption. Whereas the functions of the PIPA Team include conducting research and study as well as giving consideration to the application for permission for children adoption, giving advice in accordance with the provisions, the main tasks and functions of each member based on the stipulated provisions, submitting a report on the implementation of tasks for the Central PIPA Team to The Minister and for the Regional PIPA Team to the Governor cc Head of Social Department, and conducts guidance and supervision of the implementation of licensing for children adoption in accordance with their fields of work.The position of the Bengkulu Province Regional PIPA Team is in the capital of Bengkulu Province.

4. Obstacles in the Process of Implementing Appointment of Children through the Bengkulu Province Social Department

a) The Limitation of Human Resources (HR)
The still low

understanding of the community who become Prospective Adoptive Parents (COTA) to carry out children adoption in accordance with existing legislation so that there were still many irregularities and violations in the practice of adopting children illegally.

b) The Limitation of Budget Allocation

The available budget was very limited and minimal, so that several series of important activities to increase public understanding and awareness of children adoption according to the rules were still not optimal. The budget allocation to finance a series of activities has not been determined by the Bengkulu Province BudgetingTeam for Regional Development, since this budget is the key point in carrying out an activity, if it has been budgeted properly and in detail then the activity will run as it should.

The budget provided by the Regional Government to carry out the Children Adoption through the Provincial Social Department 
was currently very limited

only to accommodate the

Regional Consultation Team

for Children Adoption of

Bengkulu Province, while

those sourced from the

National Budget only finance

counseling related to functional

and professional occupational

allowances, National Civil

Apparatus instructor's

operational costs and

infrastructure facilities, while

funding for counseling in the

Regency/City, District and

village, was expected to share

funding from the Regional

Budget.

c) Kinship culture is still Quite High

In general, offspring have

a legal relationship based on

blood relations, including

between parents and children.

There are also legal

consequences related to

offspring with the unity of their ancestors, but the legal consequences are not all the same in all regions. As in the Bengkulu Province community in general based on the results of interviews with Social Workers, it was obtained information that based on the PEKSOS experience in the field, children who are usually adopted by the community are:

a. Children who are adopted from birth after their mother dies are generally adopted by their own families, either relatives of the mother or father of the child;

b. Children who are adopted because of their parents' divorce, these children are usually adopted by close family members, both from the mother and father;

c. Children who have many siblings and are not yet mature, these children are usually adopted by siblings from their own parents;

d. Children who are appointed based on the agreement of biological parents and adoptive parents, the appointment of these children is done by their own family or relatives themselves.

Judging from the 4 (four) things that become the background of the children 
adoption in Bengkulu Province, the most common reason was because the child was still a relative with the foster father or foster mother. Individuals as descendants (family members) have certain rights and obligations related to their position in the family concerned.

Bengkulu society in the principle of its offspring seems to emphasize more on male lines (patrilineal), as is true in the religion of Islam they adopted. Meaning to say, the influence of Islam in the development of Bengkulu society (Malay) was more assertive and clearer. However, there was also a mention that Bengkulu society adheres to the parental system (father and mother lines). Parental kinship system, which is "a family system in which each person in terms of drawing his lineage connects himself through his father and mother, and so onwards, with no one removed from a series of lineage ties."

\section{CLOSING}

\section{Conclusions}

a The Implementation of
ChildrenAdoption Licensing in Bengkulu Province has proceeded according to the procedure regulated in Government Regulation Number 54 of 2007 concerning Children Adoption, which was carried out by the Technical $O P D$ namely the Social Departmentof Bengkulu Province and the Consultation Team for Children Adoption (PIPA) of Bengkulu Province which was formed based on the Governor's Decree of Bengkulu Province, which consists of elements of the relevant department agencies that have functions in accordance with their respective fields of duty, in the process of the implementation the PIPA TEAM must coordinate and synergize with each other starting from the time of research, study as well as giving consideration to requests for permission for children adoption, giving advice in accordance with provisions and submitting reports on the results of the 
performance of duties to the

Governor cc Head of Social

Department.

b. The absence of a Regional Regulation (PERDA) as one of the legal instruments that specifically regulates the Implementation of Children Adoption in Bengkulu Province, so that the budget allocation to support the children adoption by the Bengkulu Provincial Social Department every year such as for socialization, counseling and assistance to the community particularly to the Prospective adoptive parents (COTA) was still very limited.

\section{Suggestions}

a. Social Departmentof

Bengkulu Province and Consultation Team for Children Adoption (PIPA) of Bengkulu Province can conduct hearings to the Regional House of Representatives (known as $D P R D$ in Indonesia abbreviation) through the Bengkulu Province DPRD Budget Board and the Budget Team for Regional
Development to convey the mandate of Government Regulation Number 54 Year 2007 regarding Children Adoption, in order to provide the best protection for children as well as legal certainty for adopted children in the Bengkulu Province area, for this reason there is a need for the existence of a Regional Regulation (PERDA) which can be a guideline in preparing program activities and budgeting needs in carrying out the process of adopting children by the Bengkulu Provincial Social Department.

b. Human Resources of Counseling staff from the Social Departmentof Bengkulu Province and Social Workers (PEKSOS) need to be equipped with training and skills to improve the competence of officers in conducting socialization, counseling and assistance, it was also needed to form a special Department room for Consultation/Counseling for the community as a support in providing public services regarding children adoption both at the Provincial Social Department and at the 
Regency/City Social

Department.

c. The community should be able to play an active role in supervision towards families or parties suspected of adopting children without going through legal procedures (illegal).

\section{REFERENCES}

Salim HS and Erlies Septiana Nurbani, Buku Kedua Penerapan Teori Hukum Pada Penelitian Disertasi dan Tesis, PT. Raja Grafindo Persada, Jakarta.

Soerjono Soekanto, Pengantar Penelitian Hukum, Universitas Indonesia Press, Jakarta. 1986.

Suratman and Philips Dillah,

Metode Penelitian Hukum Dilengkapi Dengan Tata Cara dan Contoh Penulisan Karya Ilmiah Bidang Hukum, CV. Alfabeta, Bandung, 2014.

Decision of Governor of Bengkulu Number IV.156.DINSOS of 2017 on Regional Consultation Team for Children Adoption of Bengkulu Province of 2017.

Government Regulation of the Republic of Indonesia Number 54 of 2007 on the Implementation of Children Adoption

Law of the Republic of Indonesia Number 23 of 2014 on Regional Government 